\title{
The Effectiveness Comparison of Virtual Laboratory and Physical Laboratory in Nurturing Students' Attitude towards Chemistry
}

\author{
Murugan Mini Ratamun, Kamisah Osman \\ National University of Malaysia, Bangi, Malaysia \\ Email:mnlmurugan@gmail.com, kamisah@ukm.edu.my
}

How to cite this paper: Ratamun, M. M., \& Osman, K. (2018). The Effectiveness Comparison of Virtual Laboratory and Physical Laboratory in Nurturing Students' Attitude towards Chemistry. Creative Education, 9, 1411-1425.

https://doi.org/10.4236/ce.2018.99105

Received: July 10, 2018

Accepted: July 23, 2018

Published: July 26, 2018

Copyright $\odot 2018$ by authors and Scientific Research Publishing Inc. This work is licensed under the Creative Commons Attribution International License (CC BY 4.0).

http://creativecommons.org/licenses/by/4.0/

(c) (i) Open Access

\begin{abstract}
The aim of the research is to compare the effectiveness of Virtual Laboratory and Physical Laboratory in students' attitude towards chemistry. The students' attitude towards chemistry is compared by gender and the interaction effect between groups and gender was studied. The instrument used in this research is Attitude Towards Chemistry Lessons Scale (ATCLS). A quasi-experimental research design with nonequivalent control group pre-survey and post-survey was used. The participants of this research are Malaysian upper secondary four science stream students. This research involved a total of 147 students, which are 64 male students and 83 female students. The two-way ANCOVA analysis showed that the effectiveness of group on the post ATCLS mean score was not significant. It concluded that the level of students' attitude towards chemistry is same when experiment is done in VLab or PLab. The effectiveness of attitude towards chemistry on gender was not significant. The analysis also showed that the interaction effect between group and gender in ATCLS is not significant. This means the group's influence on the mean score of ATCLS is not caused by the gender and the gender influence on the mean score of ATCLS is not caused by groups.
\end{abstract}

\section{Keywords}

Attitude towards Chemistry, Virtual Laboratory, Physical Laboratory, Gender

\section{Introduction}

Chemistry is a unique and interesting subject. However, chemistry subject is 
considered to be a difficult subject among Malaysian students (Chu \& Hong, 2010). Misconceptions of chemistry subject among students are caused by the content of textbooks and public perceptions of chemistry from various media. In addition, this misunderstanding is also due to friends, family members of various ethnic and cultural backgrounds. To avoid misconceptions of chemistry lesson, teachers need to focus on experiment activities at labs. Chemical experiment is an activity carried out to learn chemistry subject and this helps students in the development of scientific skills and promotes the application of creative thinking and student's scientific attitude. Experiment is very useful to develop scientific attitudes among students (Tüysüz, 2010).

In 2003, the Ministry of Education (MOE) of Malaysia has introduced Information and Communication Technology (ICT) in teaching and learning. This is in conjunction with the use of English as a medium for teaching and learning of science and mathematics subjects. All involved in teaching Science and Mathematics have been provided with laptops, Liquid Crystal Display (LCD) projectors and many compact discs (CD) of teaching and learning software. The key policies of the MOE related to ICT are to: ensure all students to be computer literate, prioritize the role and function of ICT in education and encourage the use of ICT to enhance the productivity, excellence and effectiveness of the management system in education. The use of ICT can help the school to build, modify and formulate knowledge, attitudes, feelings, beliefs and abilities of students. This will help students to acquire the 21st century skills in an easier way (Rabasco, Hus, Román-García, Del Rocío, \& Díaz, 2015).

The use of ICT in experimental teaching is a new learning method in Malaysia. For example, learning in smart schools emphasizes the use of ICT as a major component in the implementation of the teaching and learning activity (Abd Ghani, Chan, Karuppaya, \& Bazrulzaman, 2005). Experiments carried out in physical laboratory (PLab) can be done virtually using ICT technology. Experiments carried out virtually using ICT are called virtual laboratory (VLab). VLab is the center of creativity that meets every thought. Such systems need to be trusted in education and technical aspects (Drigas, Vrettaros, Koukianakis, \& Glentzes, 2005). VLab differs from the PLab by giving advantage to computer-controlled teaching and experimental pedagogy. VLab was able to enhance the interaction of teachers and students during the experiment and VLab could also save on the cost of doing experiments compared to PLab (Ibrahim, 2011).

The Ministry of Science, Technology and Innovation (MOSTI) has expressed concern that the percentage of science stream students in secondary schools across the country declined over the last few years (Fatin, Salleh, Bilal, \& Salmi$\mathrm{za}, 2014)$. Commenting on the report, MOE has pointed out that today's science learning system is more on theoretical aspect than practical. This needs to be looked back as an effort to increase the number of students who choose science stream. MOE will empower science practical training in school laboratories to overcome the problem. However, this proposal is difficult to be implemented as many schools in Malaysia do not have the perfect science laboratory. The 
equipment in the laboratory is incompatible with the current needs (BERNAMA, 2017). As such, VLab can be used to help students carry out more practical work in school. This will increase students' interest in science and also increase the number of students entering science stream.

According to Yunus \& Ali (2013), most students lose interest in chemistry are due to their own attitudes caused by the content and curriculum of chemistry subjects. The content and curriculum of chemistry have caused students to show negative attitude towards chemistry because they feel that chemistry is a difficult subject. The majority of students' negative attitudes towards chemistry learning can be changed if they perform practical or experimental work in the laboratories. Therefore, experimental teaching methods are strongly encouraged. However, some say that practical work is ineffective to motivate students while changes the interest of students in science and recommends those involved with science education to build a deeper understanding of student attitudes while building the curriculum (Abrahams, 2009). Therefore, a more flexible and fun chemical experimentation method should be used. VLab may be able to help students to use a more flexible and fun chemical experimentation. In this research, our main aim is to compare students' attitude towards chemistry subject after using VLab and PLab to do experiments. Attitude towards chemistry plays a very important role to change students' ability to solve chemistry problems. Positive attitude will help them to improve their learning ability using scientific skills and provide them with problem solving skills.

In a research conducted on 45 female students and 45 male students from three secondary schools in Minna, Nigeria found that learning using computer simulations was able to change the attitudes of students to be more motivated towards chemistry subjects (Gambari, Gbodi, Olakanmi, \& Abalaka, 2016). A study about changes in attitudes towards chemistry among 238 Kenya students also found that computer simulations can change attitudes and motivate students to learn chemistry (Keter, Wachanga, \& Anditi, 2016). Due to the rapid changes in science and technology in today's world, new methods and techniques are needed in science teaching. One of the most important teaching techniques is experimental techniques. This technique involves all the senses and enables learning to be more meaningful. This technique will be more effective if students' attitude towards science is more positive. The uses of VLab in experimental techniques have led to greater achievement and improve students attitudes toward chemistry. VLab experiments have a big role in education by providing a genuine interactive model for students. Therefore, it is proposed that virtual experiments can use in different contexts and steps (Ay \& Yilmaz, 2015).

\subsection{Virtual Laboratories}

The VLab is defined as a computer-assisted teaching through the integration of computer simulations with laboratory activities. VLab can change the concept of abstract teaching into concrete, linking the concepts learned with everyday life 
and students can learn at their own pace and needs (Stieff \& Wilensky, 2003). In this research, VLab is defined as a tool that students can use to run their own experiments using mouse to control physical actions such as pushing objects, turning objects, lifting objects, changing tools or materials, heating materials, measuring material and mixing two materials. Animation and simulation concepts are used to allow students to interact with materials and apparatus to see the results of the reaction in an experiment. In addition, the VLab is a chemistry experimental learning module developed based on Kemp's Model which integrates four basic components of instruction designs that are students, objectives, methods and assessments. So, this study is a package of teaching materials that 1) take into account the characteristics of the students, 2) learning objectives, 3) content based on theory, approach and learning strategies, and 4) assessment.

Kemp's Model has been a basic framework in the VLab development process. The Kemp Model has nine elements as shown in Figure 1. All elements are related to one another and support each other.

This model is holistic and not linear. The elements in this model are not associated with the use of lines or arrows so that designers can build modules in a flexible way. In addition to develop a module or program does not necessarily use all the nine elements contained in this model. These elements are independent because the elements do not need to be arranged in order and not necessarily started with one particular element. However, in this research, the process of developing the instruction model starts with the process of identifying the problem which the researcher will explain the VLab development process from the "instruction problem" element and ends with the "evaluation instrument" element. In the process of developing VLab, researchers have built a storyboard before all the information and content is translated into a multimedia software. Among the aspects are given attention when preparing storyboards are the sequence of content, the strategic learning of which is using Constructivism Learning Theory and Contextual Learning Approach, group organization, time and space allocation and the selection of resources that can be used. Other than that the elements outside the Kemp's Model are planning, support services, project management, reviews and evaluations but for this research only review and evaluation elements was applied. This is because time and cost to carry out this research are very limited. Additionally, these two elements are more appropriate to be applied in learning activities. The Evaluation involved in this study is a formative evaluation and summative evaluation.

\subsection{Physical Laboratories}

PLab is intended as a space used for teaching, analysis, doing research, doing real experiments with physical materials and apparatus and the production of materials at school (Pyatt \& Sims, 2012). According to Abrahams \& Millar (2008), PLab is known as practical work activities where students manipulate and observe objects and materials. In this research, PLab is defined as laboratories 


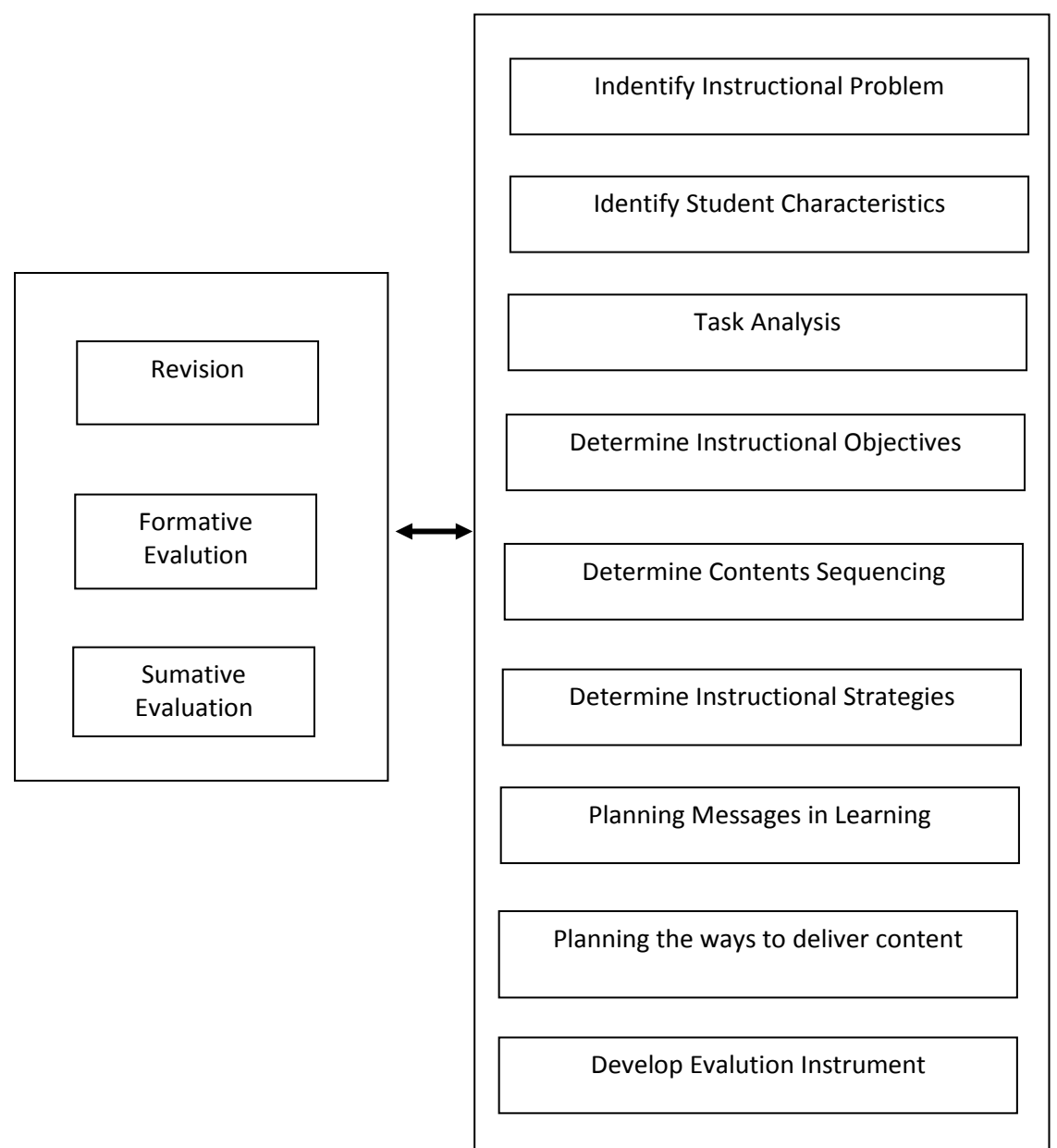

Figure 1. VLab development procedure using Kemp's Model (2007).

using actual experimental equipment and materials as well as undergoing 'hands-on' activities where students hold and experience experimental experiences like a scientist. This laboratory makes students easy to change concepts from concrete to abstract and help them to connect the concept with the real world. For the purposes of this research, concrete laboratory apparatus and materials have been used to carry out experiments in salt topic. In this research, the PLab is a physical space used to carry out practical activities for students to reinforce the chemical concept while acquiring scientific skills and cultivating scientific attitudes and pure values. The activities carried out in PLab use various approaches to meet different student abilities, needs and learning.

\section{Methodology}

\subsection{Research Design}

This research uses quasi-experimental design to compare the effectiveness of VLab (experiment group, EG) and PLab (control group, CG) on student attitudes toward chemistry. This research is also aimed to compare student attitudes towards chemistry with gender. The type of quasi-experimental design used is a 
nonequivalent control group pre-survey and post-survey. Three experiments from salt topic involved in this research. The experiments are about the confirmations of anion and cation in salt. The design of this research is shown as in Table 1.

\subsection{Instrument}

Survey questionnaire was used in this research. The questionnaire is Attitude Towards Chemistry Lessons Scale (ATCLS) developed by (Cheung, 2009). This questionnaire was used before and after the treatment (VLab \& PLab) to compare the students' attitude towards chemistry in both classes. ATCLS contained 12 items with four subscales that are liking for chemistry theory lessons (3 items), liking for chemistry laboratory work ( 3 items), evaluative beliefs about school chemistry (3 items) and behavioural tendencies to learn chemistry (3 items). ATCLS is an established survey questionnaire that was used in many studies. The Cronbach's alpha reliability for all subscales is between 0.76 to 0.86 (Cheung, 2009). Cronbach's alpha reliability coefficient in the study conducted at Turkey is 0.81 (Ayyildiz \& Tarhan, 2009) and 0.93 (Belge Can, 2012). The Cronbach's alpha reliability of pilot study in this research is 0.89 . ATCLS questionnaire is modified to a five-point Likert scales without negatively worded items (Cheung, 2009) to avoid a separate factor that allows measurements inappropriate (Spector, Van Katwyk, Brannick, \& Chen, 1997; Burke, 1999; Gotlib \& Meyer, 1986; Pilotte \& Gable, 1990; Miller \& Cleary, 1993; Schmitt \& Stults, 1985). Table 2 shows the ATCLS sub-scale and their items.

\subsection{Sample}

Three schools were randomly selected to participate in this research and all the 3 schools are National Secondary School (NSS) in Malaysia. Two schools were randomly selected to engage in real studies while another school was engaged for pilot studies. All schools that were selected must have two science stream classes. Overall, this study involved a total of 147 participants with 64 males and $83 \mathrm{fe}$ males. Table 3 shows the number of participants involved in the research.

\subsection{Data Analysis}

Data was analysed using descriptive and inference statistic. Descriptive data was discussed by using mean, standard deviation and frequency. While inferential data was discussed by using two-way ANCOVA.

Table 1. Research design.

\begin{tabular}{cccc}
\hline & \multicolumn{3}{c}{ Confirmations of Anion \& Cation } \\
\cline { 2 - 4 } & Pre-survey & X1 (VLab-EG) & Post-survey \\
\cline { 2 - 4 } Class 1 & Preatment & \\
Class 2 & Pre-survey & X2 (PLab-CG) & Post-survey \\
\hline
\end{tabular}


Table 2. ATCLS Sub-scale.

\begin{tabular}{|c|c|c|}
\hline Subscale & Number of Item & Item \\
\hline $\begin{array}{l}\text { Liking for chemistry } \\
\text { theory lessons }\end{array}$ & 3 & $\begin{array}{l}\text { Q1: I like chemistry more than any other school subjects. } \\
\text { Q5: Chemistry lessons are interesting } \\
\text { Q9: Chemistry is one of my favorite subjects }\end{array}$ \\
\hline $\begin{array}{l}\text { Liking for chemistry } \\
\text { laboratory work }\end{array}$ & 3 & $\begin{array}{l}\text { Q2: I like to do chemistry experiments } \\
\text { Q6: When I am working in the chemistry lab, I feel I am } \\
\text { doing something important } \\
\text { Q10: Doing chemistry experiments in school is fun }\end{array}$ \\
\hline $\begin{array}{l}\text { Evaluative beliefs } \\
\text { about school } \\
\text { chemistry }\end{array}$ & 3 & $\begin{array}{l}\text { Q3: Chemistry is useful for solving everyday problems } \\
\text { Q7: People must understand chemistry because it affects } \\
\text { their lives } \\
\text { Q11: Chemistry is one of the most important subjects for } \\
\text { people to study }\end{array}$ \\
\hline $\begin{array}{l}\text { Behavioural } \\
\text { tendencies to learn } \\
\text { chemistry }\end{array}$ & 3 & $\begin{array}{l}\text { Q4: I am willing to spend more time reading chemistry } \\
\text { books } \\
\text { Q8: I like trying to solve new problems in chemistry } \\
\text { Q12: If I had a chance, I would do a project in chemistry }\end{array}$ \\
\hline
\end{tabular}

Table 3. Number of participant.

\begin{tabular}{|c|c|c|c|c|}
\hline \multirow{2}{*}{ Group } & \multirow{2}{*}{ School } & \multicolumn{2}{|c|}{ Gender } & \multirow{2}{*}{ Total } \\
\hline & & Male & Female & \\
\hline \multirow{2}{*}{ Class 1} & NSS A & 12 & 18 & 30 \\
\hline & NSS B & 21 & 25 & 46 \\
\hline \multirow{2}{*}{ Class 2} & NSS A & 11 & 17 & 28 \\
\hline & NSS B & 20 & 23 & 43 \\
\hline \multicolumn{2}{|c|}{ Total } & 64 & 83 & 147 \\
\hline
\end{tabular}

\section{Research Results}

Descriptive statistics for 147 participants involved in pre and post survey are as in Table 4.

Table 4 shows that the post mean score of attitudes towards chemistry $(\mathrm{M}=$ $4.20, \mathrm{SD}=0.66)$ is higher than the pre mean score of attitude towards chemistry $(\mathrm{M}=3.37, \mathrm{SD}=1.14)$. This descriptive statistic also shows that the pre mean score of the EG $(M=3.39, \mathrm{SD}=1.12)$ is higher than the mean score $\mathrm{CG}(\mathrm{M}=$ $3.35, \mathrm{SD}=1.17)$. On the other hand, in the case of gender, the pre mean score of female $(M=3.43, S D=1.07)$ was higher than male $(M=3.30, S D=1.23)$. When compared to the pre mean score of male and female participants in the CG, the mean score of female $(\mathrm{M}=3.64, \mathrm{SD}=1.01)$ was higher than male $(\mathrm{M}=3.08, \mathrm{SD}$ $=1.26)$. While the pre mean score mean for male and female participants in the EG, the male mean score $(\mathrm{M}=3.59, \mathrm{SD}=1.15)$ was higher than female $(\mathrm{M}=$ $3.29, \mathrm{SD}=1.10)$. Referring to Table 4 , the post mean score of $\mathrm{EG}(\mathrm{M}=4.26$, SD $=0.66)$ is higher than the $C G(M=4.13, S D=0.65)$. On the other hand, the post mean score of female $(\mathrm{M}=4.22, \mathrm{SD}=0.72)$ was higher than the male mean score $(\mathrm{M}=4.17, \mathrm{SD}=0.58)$. When compared to the post mean score for male 
Table 4. Descriptive statistics: Pre-survey and post-survey ATCLS mean score for group and gender.

\begin{tabular}{|c|c|c|c|c|c|}
\hline ATCLS & Group & Gender & $\mathbf{M}$ & $\mathrm{SD}$ & $\mathbf{N}$ \\
\hline \multirow[t]{9}{*}{ Pre } & Control & Male & 3.08 & 1.26 & 37 \\
\hline & & Female & 3.64 & 1.01 & 34 \\
\hline & & Total & 3.35 & 1.17 & 71 \\
\hline & Experiment & Male & 3.59 & 1.15 & 27 \\
\hline & & Female & 3.29 & 1.10 & 49 \\
\hline & & Total & 3.39 & 1.12 & 76 \\
\hline & Total & Male & 3.30 & 1.23 & 64 \\
\hline & & Female & 3.43 & 1.07 & 83 \\
\hline & & Total & 3.37 & 1.14 & 147 \\
\hline \multirow[t]{9}{*}{ Pre } & Control & Male & 4.14 & 0.59 & 37 \\
\hline & & Female & 4.12 & 0.73 & 34 \\
\hline & & Total & 4.13 & 0.65 & 71 \\
\hline & Expeiment & Male & 4.22 & 0.58 & 27 \\
\hline & & Female & 4.29 & 0.71 & 49 \\
\hline & & Total & 4.26 & 0.66 & 76 \\
\hline & Total & Male & 4.17 & 0.58 & 64 \\
\hline & & Female & 4.22 & 0.72 & 83 \\
\hline & & total & 4.20 & 0.66 & 147 \\
\hline
\end{tabular}

and female participants in the CG, the mean score of $(\mathrm{M}=4.14, \mathrm{SD}=0.59)$ was higher than female $(\mathrm{M}=4.12, \mathrm{SD}=0.73)$. While the post mean score of male and female participants in the EG, the mean score of female $(\mathrm{M}=4.29, \mathrm{SD}=$ $0.71)$ was higher than male $(\mathrm{M}=4.22, \mathrm{SD}=0.58)$.

Table 5 shows ANCOVA analysis of the main effects and interaction effects on students' attitudes towards chemistry for experiment confirmations of anion and cation. The main effect of the group on the overall ATCLS score was not significant, $\mathrm{F}(1,142)=1.255, \mathrm{P}=0.264$. However based on descriptive statistics, the EG overall post mean score of ATCLS is higher than CG. So it can be concluded that student attitude toward chemistry in confirmations of anion and cation experiment is better when VLab is used. This shows that the VLab is more effective than the PLab method to improve students' attitude towards chemistry. The main effects of gender on overall ATCLS score were not significant, F $(1,142)=0.029, P=0.865$. However, based on descriptive statistics, the overall ATCLS post mean score of female was higher than male. It can be concluded that the attitude of female participants towards chemistry is better than male participants. The results of the ANCOVA analysis were also used to find interaction effect between group and gender based on overall score of ATCLS. Interaction results obtained were also not significant, $\mathrm{F}(1,142)=1.263, \mathrm{P}=0.263$. This 
Table 5. Two-way ANCOVA Analysis for main effect and interaction effect of Group and Gender.

\begin{tabular}{cccccc}
\hline Resources & Sum of Squares & df & Mean Square & F & P \\
\hline Group & 0.551 & 1 & 0.551 & 1.255 & 0.264 \\
Gender & 0.013 & 1 & 0.013 & 0.029 & 0.865 \\
Group ${ }^{\star}$ Gender & 0.097 & 1 & 0.097 & 0.221 & 0.639 \\
\hline
\end{tabular}

Significant level $<0.05$.

shows that the groups' influence on the overall score of ATCLS is not due to gender and the gender influence on overall score of ATCLS is not due to groups.

Table 6 shows the Estimated Marginal Means for the group and gender through the overall ATCLS mean score post.

The results showed that female participants who conducted the confirmations of anion and cation experiment using the VLab received a higher mean score than the male participants who conducted the experiment using VLab. In addition, Estimated Marginal Mean analysis results also showed that male participants who conducted confirmations of anion and cation experiments using PLab obtained a higher mean score than female participants who conducted experiments using PLab.

\section{Discussion}

Descriptive analysis shows that the mean score of student attitudes towards chemistry for the EG is higher than the CG. This shows that the overall attitude of students towards chemistry is better if the experiment is carried out using VLab as compared to PLab. Student attitude towards chemistry for experiments conducted using PLab is low because the learning method used in PLab by the teacher does not attract the students' interest. In addition, the use of PLab to carry out experiments is a common and routine method of chemistry learning. Students will feel experimental learning is not fun. Students also lose experimentation excitement, interest in chemistry subjects and are not eager to learn chemistry (Tafa, 2012). In PLab teachers prefer to conduct experimental demonstrations. This teachers intent is to save time and do not want students to make mistakes while conducting experiments because the mistakes made will result in wastage of material and time (Ibrahim, Surif, Hui, \& Yaakub, 2014; Walton, 2002). Many students have low cognitive level of chemistry and they are not interested in learning chemistry (Yee \& Fah, 2014).

Experimental methods using VLab are more effective and influence students in terms of their attitude towards chemistry. Descriptive analysis showed that the students' attitude towards chemistry was better if the students conducted experiments using the VLab compared to PLab. The difference in strategies that teachers used by conducting technology-assisted experiments has attracted and encouraged students to engage actively in experimental activities. Students feel comfortable and enjoyable when they do experiment assisted by ICT. This is 
Table 6. Estimated Marginal Mean: Interaction between Group and Gender Dependent Variable: ATCLS Post-survey.

\begin{tabular}{cccccc}
\hline Laboratory & Gender & M & SD & \multicolumn{2}{c}{$95 \%$ Confidence Interval } \\
\hline VLab & Male & $4.216^{\mathrm{a}}$ & 0.128 & 3.963 & 4.469 \\
& Female & $4.288^{\mathrm{a}}$ & 0.095 & 4.101 & 4.476 \\
\multirow{2}{*}{ PLab } & Male & $4.144^{\mathrm{a}}$ & 0.110 & 3.927 & 4.361 \\
& Female & $4.110^{\mathrm{a}}$ & 0.114 & 3.883 & 4.336 \\
\hline
\end{tabular}

a. The covariance shown in this model is rated based on the score: ATCLS pre-survey $=3.3741$.

because the use of ICT in teaching and learning greatly helps the learning process of students in school (Lee, Waxman, Wu, Michko, \& Lin, 2013; Pedersen \& Liu, 2003; Zwickl, Finkelstein, \& Lewandowski, 2012). This fun makes the students feel comfortable and wants to continue using the VLab to do the experiment. This has directly changed students attitude towards chemistry and they also actively involved in experiments activities (Achuonye, 2011; Yusuf \& Afolabi, 2010).

Using the VLab also gives students the opportunity to do experiments individually. During this research, each student was provided with a computer to carry out an experiment. Even though all experimental activities will be performed in small groups, the use of individual computers will cause students to be directly involved in experimental activities. This provides greater opportunities for students to engage in all experiments. This is different from experiments conducted using PLab perhaps there are students in a group who are not actively involved in experimental activities due to lack of apparatus and materials. The use of individual VLab offers greater flexibility for students to adapt to experiments performed according to their abilities (Lou, Abrami, \& D'Apollonia, 2001). The VLab has also been able to help students to complete the experiment in time given while the experiments requiring longer time to get results can be completed in a shorter time (Zacharia, Olympiou, \& Papaevripidou, 2008). The VLab can give exact experimental results without interference from any other factors (Pyatt \& Sims, 2012). This will help students' attitudes towards chemistry to be more positive because the disturbance factor in the actual experiment has been controlled and the experimental results can be observed accurately and clearly. All the above explanation stated that VLab is better than PLab. This explanation is based on the descriptive analysis of the research. The mean score of student attitudes towards chemistry has increased when VLab is used instead of using PLab. Even though the increase in the mean score is small, the use of the VLab in this research has succeeded to changed student attitudes towards chemistry.

Although the EG using the VLab to conduct experiments showed higher levels of student attitudes towards chemistry than the CG, but there was no significant effect on the attitude towards chemistry. This also implies that the use of PLab and VLab has an equal impact on students' attitude towards chemistry. This re- 
sult shows that the PLab also plays a role in changing student attitudes towards chemistry. This is in line with the study conducted by Reid and Shah (2007) stating that experiments conducted in the lab can help to develop students' scientific skill and assist them to study chemistry. During chemistry experiments, students can be trained to handle apparatus and they can observe experimental results. This will help the students to obtain detailed information on the process of science as well as help to increase interest and change the attitude of students towards chemistry (Patricia, 1990). VLab and PLab have the same impact on student attitudes toward chemistry.

Inferential statistics show that the effectiveness of the VLab and PLab on improving student attitudes towards chemistry among male and female are almost same where there is no significant difference in student attitudes towards chemistry between male and female students. Descriptive statistics show that the mean score of male student attitudes towards chemistry is higher than female in the experiment using PLab. This finding is equivalent to Cheung (2009) which states that the male students attitude towards chemistry in PLab is better than female students. These findings were also supported by the research of Adesoji and Raimi (2004) which also stated that experiments in PLab could improve the attitude of male students towards chemistry. This is because male students are more interested in conducting activities using concrete materials than abstract materials. They are more confident in handling real apparatus and laboratory materials when conducting experiments in PLab.

Female students, showed an increase in attitude towards chemistry when they conduct experiments using the VLab. This is because the girls are comfortable with the approach and strategic learning that is integrated in the VLab. Female students feel safe conducting experiments using the VLab because the experiments conducted do not involve actual apparatus and chemicals. This causes them to be more convinced and actively involved in experiments. This finding is equivalent to the study of Keter, Wachanga, and Anditi (2016) stating that computer-assisted experiments can change attitudes and motivate female students to learn chemistry. This may be due to the integration of various strategies and approaches that can meet the learning styles of female students. This allows students to actively engage in experimental activities conducted in the VLab. They collaboratively and mutually support each other in the group to achieve learning outcomes.

The attitude of the student depends on the achievement of students in chemistry. Studies show that female students show better academic achievement than male students (Koksal \& Berberoglu, 2014). Students with high achievement have a higher level of attitudes towards chemistry compare to those with low achievement. Female students show a change of attitude towards the importance of chemistry. Female students are more aware of the importance of chemistry in their daily lives. This is because both laboratories have been able to create a condition that gives students a precise understanding of the importance of salt in their lives. Similar findings were also presented in a study conducted by Kah 
Heng and Karpudewan (2015). However, the difference in gap between male and female students is small. This study demonstrates that laboratory activities regardless of VLab or PLab can help to reduce the gap between male and female attitude towards chemistry. In addition, appropriate teaching methods should be used to minimize gender gap performance. The method of teaching in a laboratory can ensure the improvement of the positive attitude of students towards chemistry (Adesoji \& Raimi, 2004).

\section{Conclusion}

VLab and PLab did not show a significant difference on the student attitudes towards chemistry. There is no significant difference between gender and attitudes towards chemistry and also no significant interaction effect between group and gender with attitudes towards chemistry. Both laboratories have the same or similar impact on students' attitude towards chemistry. Even though the increase in the mean score is small, the use of the VLab in chemistry experiments has succeeded to change attitudes towards chemistry. The difference in VLab effectiveness on attitudes towards chemistry may be more apparent if this laboratory is used for a longer period. Attitude can be changed if an act is repeated for a longer time (William \& Radmila, 2008). Significant change in attitudes can be obtained if all activities in the VLab are multiplied or the number of experiments in the VLab is added. Changes in VLab activities will cause the time that students use to perform activities to be longer. This will help students build positive attitudes towards chemistry. Further research is needed because the findings of this research show that the results are not significant between the CG and EG. There are some limitations that have been made in this research due to cost and time. Many improvements can be made so that further research that is implemented can give more effective results. The improvements are like: developing VLab for other topics, using different research location, increasing the number of participants, using different methodology and analysis, and increasing time of research.

\section{Acknowledgements}

The authors express their appreciation to Ministry of Education Malaysia (MOE), State Education Department, District Education Officers, schools' teachers and students for their involvement in this research.

\section{Conflicts of Interest}

The authors declare no conflicts of interest regarding the publication of this paper.

\section{References}

Abd Ghani, J., Chan, H. L., Karuppaya, K. S., \& Bazrulzaman, B. (2005). Konsep dan Pelaksanaan Sekolah Bestari Di Malaysia. Seminar Pendidikan. 
Abrahams, I. (2009). Does Practical Work Really Motivate? A Study of the Affective Value of Practical Work in Secondary School Science. International Journal of Science Education, 31, 2335-2353. https://doi.org/10.1080/09500690802342836

Abrahams, I., \& Millar, R. (2008). Does Practical Work Really Work? A Study of the Effectiveness of Practical Work as a Teaching and Learning Method in School Science. International Journal of Science Education, 30, 1945-1969. https://doi.org/10.1080/09500690701749305

Achuonye, A. (2011). Using Computer in Science Class: The Interactive Effect of Gender. Journal of African Studies and Development, 3, 131-134.

Adesoji, F. A., \& Raimi, S. M. (2004). Effects of Enhanced Laboratory Instructional Technique on Senior Secondary Student's Attitude toward Chemistry in Oyo Township, Oyo State, Nigeria. Journal of Science Education and Technology, 13, 377-385. https://doi.org/10.1023/B:JOST.0000045465.81437.3b

Ay, Ö. S., \& Yilmaz, S. (2015). Effects of Virtual Experiments Oriented Science Instruction on Students' Achievement and Attitude. Elementary Education Online, 14, 609-620.

Ayyildiz, Y., \& Tarhan, L. (2009). Effect of Case Studies on Primary School Teaching Students' Attitudes toward Chemistry Lesson. H. U. Journal of Education, 43, 62-70.

Belge Can, H. (2012). Students' Attitudes toward School Chemistry: The Effect of Interaction between Gender and Grade Level. Asia-Pacific Forum on Science Learning and Teaching, 13, 1-16.

BERNAMA. (2017). KPM akan Memperkasakan Amali Di Makmal Sains Sekolah. Nilai: Bernama.Com.

Burke, B. G. (1999). Item Reversals and Response Validity in the Job Diagnostic Survey. Psychological Reports, 85, 213-219. https://doi.org/10.2466/pr0.1999.85.1.213

Cheung, D. (2009). Students' Attitudes toward Chemistry Lessons: The Interaction Effect between Grade Level and Gender. Research in Science Education, 39, 75-91. https://doi.org/10.1007/s11165-007-9075-4

Chu, C. K., \& Hong, K. Y. (2010). Misconceptions in the Teaching of Chemistry in Secondary Schools in Singapore \& Malaysia. In Proceedings of the Sunway Academic Conference 2010 (pp. 1-10). Petaling Jaya: Sunway University College.

Drigas, A. S., Vrettaros, J., Koukianakis, L. G., \& Glentzes, J. G. (2005). A Virtual Lab and E-Learning System for Renewable Energy Sources. In International Conference on Educational Technologies (Vol. 5, pp. 149-153). Tenerife, Canary Islands, Spain: Net Media Lab of NCSR Demokritos.

http://www.scopus.com/inward/record.url?eid=2-s2.0-33645137921\&partnerID=tZOtx 3y1

Fatin, A., Salleh, A. M., Bilal, A. M., \& Salmiza, S. (2014). Faktor penyumbang kepada kemerosotan penyertaan pelajar dalam aliran sains: satu analisis sorotan tesis. In Sains Humanika (p. 17). Johor Bahru: Universiti Teknologi Malaysia.

Gambari, I. A., Gbodi, B. E., Olakanmi, E. U., \& Abalaka, E. N. (2016). Promoting Intrinsic and Extrinsic Motivation among Chemistry Students Using Computer-Assisted Instruction. Contemporary Educational Technology, 7, 25-46.

Gotlib, I. H., \& Meyer, J. P. (1986). Factor Analysis of the Multiple Affect Adjective Check List: A Separation of Positive and Negative Affect. Journal of Personality and Social Psychology, 50, 1161-1165. https://doi.org/10.1037/0022-3514.50.6.1161

Ibrahim, D. (2011). Engineering Simulation with MATLAB: Improving Teaching and Learning Effectiveness. Procedia Computer Science, 3, 853-858.

https://doi.org/10.1016/j.procs.2010.12.140 
Ibrahim, N. H., Surif, J., Hui, K. P., \& Yaakub, S. (2014). “Typical” Teaching Method Applied in Chemistry Experiment. Procedia-Social and Behavioral Sciences, 116, 4946-4954. https://doi.org/10.1016/j.sbspro.2014.01.1054

Kah Heng, C., \& Karpudewan, M. (2015). The Interaction Effects of Gender and Grade Level on Secondary School Students' Attitude towards Learning Chemistry. Eurasia Journal of Mathematics Science \& Technology Education, 11, 889-898.

Keter, J. K., Wachanga, S. W., \& Anditi, Z. O. (2016). Effect of Gender on Motivation in Chemistry Lessons When Students Are Taught through Computer Based Cooperative Mastery Learning (CBCML) in Bomet County, Kenya. Journal of Educational Policy and Entrepreneurial Research, 3, 24-35.

Koksal, E. A., \& Berberoglu, G. (2014). The Effect of Guided-Inquiry Instruction on 6th Grade Turkish Students' Achievement, Science Process Skills, and Attitudes toward Science. International Journal of Science Education, 36, 66-78.

https://doi.org/10.1080/09500693.2012.721942

Lee, Y.-H., Waxman, H., Wu, J.-Y., Michko, G., \& Lin, G. (2013). Revisit the Effect of Teaching and Learning with Technology. Journal of Educational Technology \& Society, 16, 133-146.

Lou, Y., Abrami, P., \& D’Apollonia, S. (2001). Small Group and Individual Learning with Technology: A Meta-Analysis. Review of Educational Research, 71, 449-521. https://doi.org/10.3102/00346543071003449

Miller, T. R., \& Anne Cleary, T. (1993). Direction of Wording Effects in Balanced Scales. Educational and Psychological Measurement, 53, 51-60. https://doi.org/10.1177/0013164493053001004

Patricia, E. B. (1990). The Role of the Laboratory in Science Teaching. Columbus, OH: National Association for Research in Science Teaching, Ohio State University. http://www.tandfonline.com/doi/pdf/10.1080/00207540902847447

Pedersen, S., \& Liu, M. (2003). Teachers' Beliefs about Issues in the Implementation of a Student-Centered Learning Environment. Educational Technology Research and Development, 51, 57-76. https://doi.org/10.1007/BF02504526

Pilotte, W. J., \& Gable, R. K. (1990). The Impact of Positive and Negative Item Stems on the Validity of a Computer Anxiety Scale. Educational and Psychological Measurement, 50, 603-610. https://doi.org/10.1177/0013164490503016

Pyatt, K., \& Sims, R. (2012). Virtual and Physical Experimentation in Inquiry-Based Science Labs: Attitudes, Performance and Access. Journal of Science Education and Technology, 21, 133-147. https://doi.org/10.1007/s10956-011-9291-6

Rabasco, F., Hus, V., Román-García, S., Del Rocío, M., \& Díaz, R. (2015). ICT in Education of the 21ST Century Citizen. Similarities and Differences between Spain and Slovenia. General and Professional Education, 1, 22-30.

Reid, N., \& Shah, I. (2007). The Role of Laboratory Work in University Chemistry. Chemistry Education Research and Practice, 8, 172-185.

https://doi.org/10.1039/B5RP90026C

Schmitt, N., \& Stults, D. M. (1985). Factors Defined by Negatively Keyed Items: The Result of Careless Respondents? Applied Psychological Measurement, 9, 367-373. https://doi.org/10.1177/014662168500900405

Spector, P. E., Van Katwyk, P. T., Brannick, M. T., \& Chen, P. Y. (1997). When Two Factors Don't Reflect Two Constructs: How Item Characteristics Can Produce Artifactual Factors. Journal of Management, 23, 659-677.

https://doi.org/10.1177/014920639702300503 
Stieff, M., \& Wilensky, U. (2003). Connected Chemistry, Incorporating Interactive Simulations into the Chemistry Classroom. Journal of Science Education and Technology, 12, 285. https://doi.org/10.1023/A:1025085023936

Tafa, B. (2012). Laboratory Activities and Students Practical Performance: The Case of Practical Organic Chemistry I Course of Haramaya University. AJCE, 2, 2227-5835.

Tüysüz, C. (2010). The Effect of the Virtual Laboratory on Students' Achievement and Attitude in Chemistry. International Online Journal of Educational Sciences, 2, 37-53.

Walton, P. H. (2002). On the Use of Chemical Demonstrations in Lectures. The Royal Society of Chemistry Journal, 6, 22-27. http://www.rsc.org/images/Vol_6_No1_tcm18-7042.pdf

William, C., \& Radmila, P. (2008). Frontier of Social Psychology Attitudes and Attitude Change. New York: Psychology Press. https://doi.org/10.1017/CBO9781107415324.004

Yee, A. L. S., \& Fah, L. Y. (2014). Sikap dan Kebimbangan Kimia Dalam Kalangan Pelajar Aliran Sains: Satu Pendekatan Pemodelan Persamaan Struktural (SEM). Jurnal Pemikir Pendidikan (Journal for Educational Thinkers), 5, 99-117.

Yunus, F. W., \& Ali, Z. M. (2013). Attitude towards Learning Chemistry among Secondary School Students in Malaysia. Journal of Asian Behavioural Studies, 3, 1-11.

Yusuf, M. O., \& Afolabi, A. O. (2010). Effects of Computer Assisted Instruction (CAI) on Secondary School Students' Performance in Biology. Turkish Online Journal of Educational Technology, 9, 62-69.

Zacharia, Z. C., Olympiou, G., \& Papaevripidou, M. (2008). Effects of Experimenting with Physical and Virtual Manipulatives on Students' Conceptual Understanding in Heat and Temperature. Journal of Research in Science Teaching, 45, 1021-1035.

https://doi.org/10.1002/tea.20260

Zwickl, B. M., Finkelstein, N., \& Lewandowski, H. J. (2012). The Process of Transforming an Advanced Lab Course: Goals, Curriculum, and Assessments. American Journal of Physics, 81, 63. 